\title{
Multiple plasma enzyme activities in liver disease
}

\author{
T. HARGREAVES, I. JANOTA, AND M. J. H. SMITH \\ From the Department of Chemical Pathology, King's College Hospital Medical School, \\ Denmark Hill, London
}

SYNOPSIS The measurement of the plasma activities of glutamic-oxaloacetic and glutamic-pyruvic transaminases, aldolase, cholinesterase, and isocitric, lactic, and phosphogluconic dehydrogenases in random samples of blood was found to be of no value in the differential diagnosis of hepatitis, obstructive jaundice, hepatic cirrhosis, and neoplastic conditions involving the liver. Serial determinations of the enzyme activities provided useful information about the course of certain hepatic disorders, particularly acute viral hepatitis.

In recent years an increasing amount of attention has been given to the fluctuations of blood enzyme activities in liver disease. Numerous workers (cf. Greenberg and Harper, 1960) have shown that one or more of the many enzymes present in serum may be abnormal in various types of hepatic dysfunction. It seemed possible that characteristic patterns of blood enzyme abnormalities might be distinguished for particular disorders of the liver. We have therefore studied the variation in the plasma activities of several enzymes belonging to four different groups (glycolytic, dehydrogenases, transaminases, and esterases) in patients with hepatitis, obstructive jaundice, cirrhosis, and neoplastic conditions involving the liver. The determinations were performed on single random specimens of blood and also on serial samples obtained from selected patients.

\section{MATERIALS AND METHODS}

PLASMA ENZYME ACTIVITIES The enzyme activities measured, together with the analytical methods and incubation temperatures used, are given in Table I.

Two difficulties arise with respect to the units employed by various workers to express an enzyme activity. The principal source of possible error is that the activity of an enzyme may be determined by different methods involving the definition of different units and these may not be interconvertible. Thus, two or even more, normal ranges and abnormal responses for a particular enzyme may be encountered in the literature. The units employed in the present work are those defined in the analytical methods listed in Table I and may not necessarily be equivalent to units defined by other workers. A second difficulty relates to the volume of plasma or serum used to define the normal range. Enzyme activities are usually expressed in terms of $1 \mathrm{ml}$. of plasma or serum. However, alkaline phosphatase and cholinesterase activities have been defined for many years in terms of $100 \mathrm{ml}$. of plasma and serum, and it would cause some confusion to alter this long-established practice. Enzyme activities are extremely dependent upon temperature but there is, as yet, no general agreement about either an internationally standard temperature at which enzyme activities should be measured or an appropriate correction factor by which results obtained at different temperatures could be interconverted. We have therefore employed two widely used incubation temperatures $\left(25^{\circ}\right.$ and $37^{\circ} \mathrm{C}$.) and have not attempted to apply corrections.

The methods for the determination of aldolase, the two transaminases, alkaline phosphatase, and cholinesterase were colorimetric procedures and the final determination of the optical densities were made with a Hilger Spekker absorptiometer. The dehydrogenase estimations were based on the conversion of the reduced forms of either diphosphorypyridine or triphosphopyridine nucleotides to their corresponding oxidized forms. These latter reactions were measured by the changes in optical density at $340 \mathrm{~m} \mu$ using a Hilger Uvispek spectrophotometer. The normal range for each plasma enzyme activity was determined by analysing random blood specimens, collected into heparinized bottles, from 50 normal adult subjects.

Other biochemical examinations included the estimation of serum bilirubin (Malloy and Evelyn, 1937), the serum thymol turbidity test (Maclagen, 1944), and qualitative tests for urinary bilirubin, urobilinogen, and urobilin (Harrison, 1957).

PATIENTS The plasma enzyme activities and other liver function tests were performed on blood samples taken at random from 53 patients. They included patients in the 
TABLE I

PLASMA ENZYME ACTIVITIES MEASURED

\begin{tabular}{lll} 
Group Activity & Enzyme & Incubation \\
\hline Glycolytic & Aldolase & 37 \\
Transaminase & $\left\{\begin{array}{l}\text { Glutamic-oxaloacetic } \\
\text { Glutamic-pyruvic }\end{array}\right.$ \\
Dehydrogenase & $\left\{\begin{array}{l}\text { Lactic } \\
\text { Isocitric } \\
\text { Phosphogluconic }\end{array}\right.$ \\
Esterase & $\left\{\begin{array}{l}\text { Alkaline phosphatase } \\
\text { Cholinesterase }\end{array}\right.$
\end{tabular}

wards and from the out-patient departments referred to the laboratory for the investigation of liver function. The patients were divided into the groups shown in Table II and the clinical diagnosis was subsequently confirmed by needle biopsy of the liver, by examination of bone marrow or lymph nodes in the case of five patients,

\section{TABLE II}

PATIENTS INVESTIGATED

\begin{tabular}{|c|c|c|}
\hline Clinical Group & & Number of Patients \\
\hline Infective hepatitis & & 7 \\
\hline Obstructive jaundice & $\left\{\begin{array}{l}\text { Gall stones } \\
\text { Carcinoma } \\
\text { Biliary cirrhosis }\end{array}\right.$ & $\left.\begin{array}{r}12 \\
7 \\
6\end{array}\right\} 25$ \\
\hline Hepatic cirrhosis & Secondary carcinor & $67^{12}$ \\
\hline Neoplastic conditions & $\left\{\begin{array}{l}\text { Reticulosarcoma } \\
\text { Hodgkin's disease }\end{array}\right.$ & $\left.\begin{array}{l}1 \\
2\end{array}\right\} 9$ \\
\hline
\end{tabular}

at operation for 24 patients, and at necropsy for 12 who died. For the remainder the diagnosis was considered to be established by a combination of the clinical evidence and the results of conventional liver function tests for urinary bile pigments, serum bilirubin, and serum thymol turbidity. Serial specimens were obtained at weekly intervals from a number of patients selected from those contained in Table II. Analyses for the plasma enzyme activities and other liver functions were continued as far as possible throughout the course of the disease. The cases studied included a mild infective hepatitis of short duration, a more severe infective hepatitis of prolonged duration, a cirrhosis with portal hypertension, a carcinoma of the bronchus with massive secondary deposits in the liver, and a case of Hodgkin's disease involving the liver before and during treatment with nitrogen mustard and $x$-ray therapy.

\section{RESULTS}

NORMAL SUBJECTS The mean values and normal ranges for the plasma enzyme activities under our laboratory conditions were determined in $\mathbf{5 0}$ normal subjects and the results are given in Table III.

The results for the enzyme activities are in good agreement with those observed in normal subjects by the great majority of other workers (King, 1959),
Analytical Method

Sibley and Lehninger (1949)

$\{$ Reitman and Frankel (1957)

Kaltenbach et al. (1957)

$\{$ Wolfson and Williams-Ashman (1957)

SPowell and Smith (1954)

De la Huerga, Yesinick, and Popper (1952)

TABLE III

NORMAL VALUES FOR PLASMA ENZYME ACTIVITIES

\begin{tabular}{|c|c|c|c|}
\hline Enzyme & Mean & Range & \\
\hline Aldolase & 4 & $1-8$ & \\
\hline Glutamic-oxaloacetic transaminase & 14 & 6- 31 & \\
\hline Glutamic-pyruvic transaminase & 9 & $0-21$ & per $\mathrm{ml}$. of \\
\hline Lactic dehydrogenase & 19 & 6- 42 & plasma \\
\hline Isocitric dehydrogenase & 112 & $40-240$ & \\
\hline Phosphogluconic dehydrogenase & 134 & $40-280$ & \\
\hline Alkaline phosphatase & 8 & $4-13$ & per \\
\hline Cholinesterase & 234 & $121-317$ & of plasma \\
\hline
\end{tabular}

except that the mean value for lactic dehydrogenase obtained in the present work is lower than the mear of 30.6 units reported by Kaltenbach, Becker, an Bernstein (1957) who used the same method of estimation.

RANDOM SPECIMENS FROM PATIENTS WITH LIVER DISEASE The results are given in Table IV, expresse as the percentages of abnormal results for each. plasma enzyme activity found in each clinical group and also for the total number of patients.

All the clinical groups showed appreciable per 3 centages of abnormal values for the enzymis activities and no characteristic patterns of plasmaे enzyme abnormalities could be distinguished fo the types of liver disease studied in the present work? The results of the thymol turbidity test offered mor positive guidance in the differential diagnosis of infective hepatitis and obstructive jaundice than anf of the plasma enzyme activities studied.

SERIAL ESTIMATIONS OF PLASMA ENZYME ACTIVIT These were done in several conditions affecting the liver.

Infective hepatitis Two cases of infective hepatiti both in young male adults, were studied. The first example was that of a mild hepatitis of relativel short duration. The patient gave a history of on week of nausea and some vomiting, but was nof seen until he had become clinically jaundiced. The serum bilirubin level never exceeded $5 \mathrm{mg}$. per $100 \mathrm{~m}$ and returned to normal within five weeks. He w\&8 
TABLE IV

PLASMA ENZYME ACTIVITIES IN RANDOM BLOOD SAMPLES ${ }^{1}$

Clinical Group Plasma Enzyme Activities

\begin{tabular}{lllllllll}
\hline Aldolase & $\begin{array}{l}\text { Glutamic- } \\
\text { oxaloacetic } \\
\text { Trans- } \\
\text { aminase }\end{array}$ & $\begin{array}{l}\text { Glutamic- } \\
\text { pyruvic } \\
\text { Trans- } \\
\text { aminase }\end{array}$ & $\begin{array}{l}\text { Lactic } \\
\text { Dehydro- } \\
\text { genase }\end{array}$ & $\begin{array}{l}\text { Isocitric } \\
\text { Dehydro- } \\
\text { genase }\end{array}$ & $\begin{array}{l}\text { Phospho- } \\
\text { gluconic } \\
\text { Dehydro- } \\
\text { genase }\end{array}$ & $\begin{array}{l}\text { Alkaline } \\
\text { Phosphatase }\end{array}$ & $\begin{array}{l}\text { Cholin- } \\
\text { esterase }\end{array}$ & $\begin{array}{l}\text { Serum } \\
\text { Thymol } \\
\text { Turbidity Test }\end{array}$ \\
\hline
\end{tabular}

\begin{tabular}{|c|c|c|c|c|c|c|c|c|c|}
\hline $\begin{array}{l}\text { Hepatitis } \\
\text { Obstructive } \\
\text { Cirrhosis } \\
\text { Neoplastic } \\
\text { All cases }\end{array}$ & $\begin{array}{l}85 \\
35 \\
65 \\
55 \\
55\end{array}$ & $\begin{array}{l}85 \\
80 \\
65 \\
65 \\
75\end{array}$ & $\begin{array}{l}85 \\
60 \\
50 \\
55 \\
60\end{array}$ & $\begin{array}{l}55 \\
20 \\
40 \\
65 \\
40\end{array}$ & $\begin{array}{l}85 \\
30 \\
50 \\
45 \\
45\end{array}$ & $\begin{array}{l}30 \\
20 \\
50 \\
20 \\
25\end{array}$ & $\begin{array}{l}55 \\
95 \\
75 \\
45 \\
75\end{array}$ & $\begin{array}{l}55 \\
35 \\
25 \\
35 \\
40\end{array}$ & $\begin{array}{r}55 \\
0 \\
50 \\
10\end{array}$ \\
\hline
\end{tabular}

'Results are expressed as percentages of abnormal values for each enzyme activity.

TABLE V

PLASMA ENZYME RESULTS IN MILD HEPATITIS OF SHORT DURATION

\begin{tabular}{|c|c|c|c|c|c|c|c|c|c|}
\hline Day & $\begin{array}{l}\text { Bilirubin } \\
\text { (mg./100ml.) }\end{array}$ & Aldolase & $\begin{array}{l}\text { Glutamic- } \\
\text { oxaloacetic } \\
\text { Transaminase }\end{array}$ & $\begin{array}{l}\text { Glutamic- } \\
\text { pyruvic } \\
\text { Transaminase }\end{array}$ & $\begin{array}{l}\text { Lactic } \\
\text { Dehydro- } \\
\text { genase }\end{array}$ & $\begin{array}{l}\text { Isocitric } \\
\text { Dehydro- } \\
\text { genase }\end{array}$ & $\begin{array}{l}\text { Phospho- } \\
\text { gluconic } \\
\text { Dehydrogenase }\end{array}$ & $\begin{array}{l}\text { Alkaline } \\
\text { Phosphatase }\end{array}$ & $\begin{array}{l}\text { Cholin- } \\
\text { esterase }\end{array}$ \\
\hline 1 & $4 \cdot 7$ & 42 & 830 & 730 & 36 & 1,040 & 680 & 16 & 98 \\
\hline 8 & $4 \cdot 8$ & 8 & 220 & 680 & 25 & 140 & 80 & 26 & 47 \\
\hline 15 & $1 \cdot 7$ & 4 & 50 & 130 & 13 & 170 & 60 & 18 & 250 \\
\hline 22 & 1.5 & 6 & 50 & 60 & 18 & 220 & 120 & 14 & 220 \\
\hline 29 & $1 \cdot 2$ & 3 & 34 & 40 & 25 & 150 & 100 & 10 & 310 \\
\hline 36 & 0.9 & 6 & 25 & 18 & 16 & 100 & 80 & 6 & 250 \\
\hline 43 & 0.5 & 4 & 20 & 10 & 20 & 120 & 160 & 6 & 280 \\
\hline
\end{tabular}

not acutely ill and made an uneventful recovery. Serial estimations of the plasma enzyme activities and other liver function tests were made at weekly intervals for six weeks and the results are shown in Table V.

The results show that all the plasma enzyme activities, with the exception of the lactic dehydrogenase, showed abnormal values when the patient was first seen. The aldolase, glutamic-oxaloacetic transaminase, isocitric dehydrogenase, phosphogluconic dehydrogenase. and cholinesterase activities returned to normal before the serum bilirubin decreased from its maximum concentration, whereas the alkaline phosphatase and glutamic-pyruvic transaminase activities decreased more slowly. The liver damage therefore appeared to be reflected in the high proportion of abnormal enzyme activities. However, this patient was not seen in the pre-icteric stage of the disease, when damage to the liver parenchyma had probably occurred and the time relation of the plasma enzyme activity disturbances to a rising serum bilirubin concentration could not be established.

The second case of infective heptatitis was studied in the pre-icteric stage, i.e, before clinical jaundice had supervened. Abnormally high values for the activities of the two transaminases were found during the period that the total serum bilirubin concentration increased from normal to $7 \mathrm{mg}$. per
$100 \mathrm{ml}$, at which point all the other enzyme activities, with the exception of lactic dehydrogenase, became abnormal. Thus, the plasma transaminase activities gave an indication of liver damage before overt jaundice occurred. The detailed results for this patient are shown in Fig. 1.

As in the case of the mild hepatitis, all the enzyme activities, except lactic dehydrogenase, showed abnormal values during the period that the jaundice was increasing. The serum bilirubin level reached $26 \mathrm{mg}$. per $100 \mathrm{ml}$., remained above $20 \mathrm{mg}$. for several weeks, and then slowly returned to normal. The majority of the abnormal enzyme activities returned to normal before the bilirubin had reached its peak but the alkaline phosphatase tended to remain slightly high. On the twenty-sixth day of the illness the patient had a further bout of nausea and vomiting and was considered on clinical grounds to have suffered a relapse. This episode was not accompanied by any further changes in the bilirubin concentration, in the thymol turbidity, alkaline phosphatase, or in the tests for urinary pigments. However, the glutamic-oxaloacetic transaminase, glutamic-pyruvic transaminase, isocitric dehydrogenase, and phosphogluconic dehydrogenase showed increased activities and the cholinesterase showed abnormally low values coinciding with the clinical relapse. The aldolase, which showed abnormal values at the beginning of the disease, failed to show this 

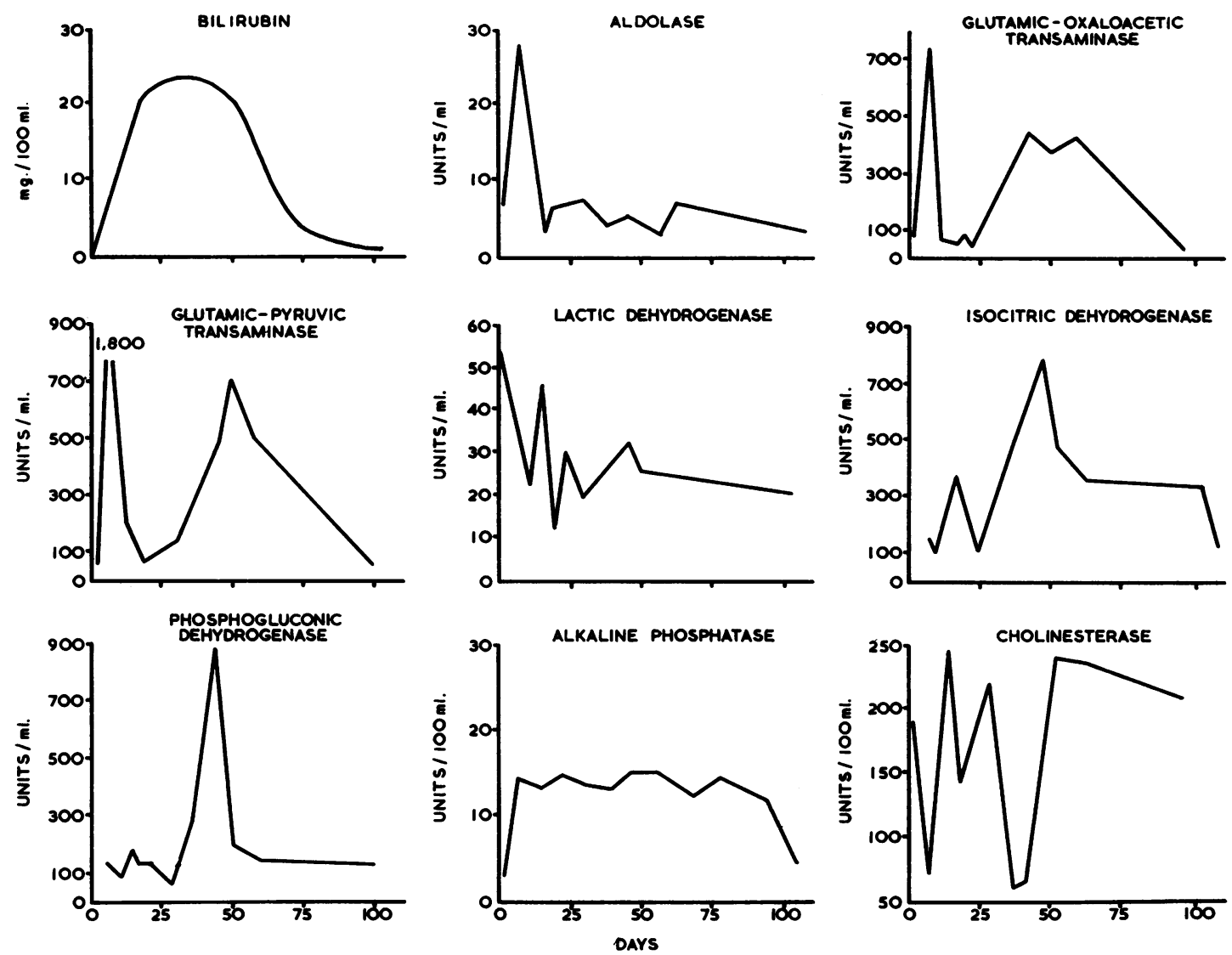

FIG. 1. Plasma enzyme activities and bilirubin concentrations in severe infective hepatitis.

secondary response. The abnormal plasma enzyme activities all returned to normal with the eventual subsidence of the jaundice. It therefore appears that some of the plasma enzymes (glutamic-oxaloacetic transaminase, glutamic-pyruvic transaminase, phosphogluconic dehydrogenase, isocitric dehydrogenase, and cholinesterase) were more sensitive indices of further liver damage during a clinical relapse than were the more conventional liver function tests such as the alkaline phosphatase, thymol turbidity, and urine pigments. The serial results with lactic dehydro- 0 genase were very inconsistent in both cases of 2 hepatitis and aldolase rarely showed abnormalo values.

Cirrhosis A woman, aged 55, with cirrhosis of을 the liver and portal hypertension, had numerous episodes of severe haemorrhage from oesophogeal ${ }^{\mathrm{r}}$ varices which necessitated repeated blood trans- $N$

TABLE VI

PLASMA ENZYME ACTIVITIES IN CIRRHOSIS

\begin{tabular}{|c|c|c|c|c|c|c|c|c|c|}
\hline Day & $\begin{array}{l}\text { Bilirubin } \\
\text { (mg./100ml.) }\end{array}$ & Aldolase & $\begin{array}{l}\text { Glutamic- } \\
\text { oxaloacetic } \\
\text { Transaminase }\end{array}$ & $\begin{array}{l}\text { Glutamic- } \\
\text { pyruvic } \\
\text { Transaminase }\end{array}$ & $\begin{array}{l}\text { Lactic } \\
\text { Dehydro- } \\
\text { genase }\end{array}$ & $\begin{array}{l}\text { Isocitric } \\
\text { Dehydro- } \\
\text { genase }\end{array}$ & $\begin{array}{l}\text { Phospho- } \\
\text { gluconic } \\
\text { Dehydrogenase }\end{array}$ & $\begin{array}{l}\text { Alkaline } \\
\text { Phosphatase }\end{array}$ & $\begin{array}{l}\text { Cholin- } \\
\text { esterase }\end{array}$ \\
\hline $\begin{array}{r}1 \\
16 \\
37 \\
65 \\
105 \\
120\end{array}$ & $\begin{array}{l}4 \cdot 8 \\
5 \cdot 2 \\
5 \cdot 4 \\
6 \cdot 6 \\
4 \cdot 2 \\
5 \cdot 5\end{array}$ & $\begin{array}{r}1 \\
6 \\
8 \\
4 \\
16 \\
9\end{array}$ & $\begin{array}{r}102 \\
130 \\
90 \\
125 \\
80 \\
120\end{array}$ & $\begin{array}{r}60 \\
56 \\
26 \\
80 \\
74 \\
155\end{array}$ & $\begin{array}{r}132 \\
120 \\
70 \\
25 \\
28 \\
20\end{array}$ & $\begin{array}{r}80 \\
60 \\
80 \\
120 \\
520 \\
170\end{array}$ & $\begin{array}{r}150 \\
200 \\
80 \\
130 \\
500 \\
220\end{array}$ & $\begin{array}{l}86 \\
70 \\
66 \\
73 \\
80 \\
32\end{array}$ & $\begin{array}{r}66 \\
80 \\
190 \\
65 \\
170 \\
90\end{array}$ \\
\hline
\end{tabular}


fusions. Serial determinations of the plasma enzyme activities were performed during a period of four months from her first attendance as an out-patient until her death as a result of haemorrhage. The results (Table VI) show that the two transaminases and the alkaline phosphatase remained consistently high during the course of the disease, as did the serum bilirubin. The cholinesterase exhibited a fluctuating behaviour and the dehydrogenases and aldolase showed isolated abnormal values.

Hepatic metastases A man, aged 69, died of carcinoma of the bronchus with massive secondary deposits in the liver, enzyme studies being made during a period of 23 days before his death (Table VII). The serum bilirubin rose to a fairly steady acetic transaminase, glutamic-pyruvic transaminase, and cholinesterase returned to normal with clinical improvement whereas the alkaline phosphatase remained high although somewhat decreased after treatment. The dehydrogenase values were never found to be high.

\section{DISCUSSION}

The present work was designed to answer two questions. First, does the analysis of random blood specimens for multiple enzyme activities provide a useful laboratory aid in the differential diagnosis of liver disease? This question was considered to be of some practical importance since clinical laboratories

TABLE VII

PLASMA ENZYME ACTIVITIES IN HEPATIC METASTASES

\begin{tabular}{|c|c|c|c|c|c|c|c|c|c|}
\hline Day & $\begin{array}{l}\text { Bilirubin } \\
(\mathrm{mg} . / 100 \mathrm{ml} .)\end{array}$ & Aldolase & $\begin{array}{l}\text { Glutamic- } \\
\text { oxaloacetic } \\
\text { Transaminase }\end{array}$ & $\begin{array}{l}\text { Glutamic- } \\
\text { pyruvic } \\
\text { Transaminase }\end{array}$ & $\begin{array}{l}\text { Lactic } \\
\text { Dehydro- } \\
\text { genase }\end{array}$ & $\begin{array}{l}\text { Isocitric } \\
\text { Dehyro- } \\
\text { genase }\end{array}$ & $\begin{array}{l}\text { Phospho- } \\
\text { gluconic } \\
\text { Dehydrogenase }\end{array}$ & $\begin{array}{l}\text { Alkaline } \\
\text { phosphatase }\end{array}$ & $\begin{array}{l}\text { Cholin- } \\
\text { esterase }\end{array}$ \\
\hline 1 & 0.6 & 20 & 25 & 12 & 67 & 240 & - & 5 & - 146 \\
\hline 6 & 0.7 & 18 & 36 & 30 & 45 & 840 & 170 & 36 & 130 \\
\hline 11 & $4 \cdot 5$ & 62 & 220 & 113 & 100 & 300 & 280 & 43 & 8 \\
\hline 17 & 6.0 & 18 & 270 & 50 & 105 & 360 & 140 & 65 & 45 \\
\hline 18 & 5.8 & 5 & 140 & 30 & 170 & 400 & 72 & 54 & 120 \\
\hline 22 & 6.6 & 8 & 180 & 72 & 70 & 720 & 160 & 6 & 160 \\
\hline
\end{tabular}

level of $6 \mathrm{mg} . / 100 \mathrm{ml}$, the transaminases, isocitric dehydrogenase, and lactic dehydrogenase remained consistently high and the cholinesterase was abnormally low on two occasions. The alkaline phosphatase and aldolase levels were raised until the terminal stages of the illness when they fell to normal levels. This terminal fall in the alkaline phosphatase was also observed in several other cases of hepatic metastases and also of cirrhosis.

Hodgkin's disease involving the liver A man, aged 42, with Hodgkin's disease and severe ascites, was treated with nitrogen mustards and deep $x$-ray therapy and showed clinical improvement. The plasma enzyme activities were measured on several occasions before, during, and after the treatment (Table VllI).

The abnormal values found for glutamic-oxalo- are frequently presented with such specimens. In Table IV the results have been expressed as the percentages of abnormal values found for each enzyme activity in each clinical group. All the clinical groups showed appreciable numbers with abnormal values for each enzyme and it does not appear that the incorporation of these particular enzyme measurements in the normal battery of liver function tests is justified. Sterkel, Spencer, Wolfson, and Williams-Ashman (1958) have stated that serum isocitric dehydrogenase is seldom abnormal in extrahepatic obstruction but its activity was elevated in $30 \%$ of cases of obstructive jaundice in the present series and compared unfavourably with the thymol turbidity test in the differentiation of acute hepatitis and posthepatic jaundice. The well-known combination of an alkaline phosphatase and thymol turbidity

TABLE VIII

PLASMA ENZYME RESULTS IN HODGKIN'S DISEASE

\begin{tabular}{|c|c|c|c|c|c|c|}
\hline Day & Treatment & $\begin{array}{l}\text { Bilirubin } \\
\text { (mg./100ml.) }\end{array}$ & $\begin{array}{l}\text { Glutamic-oxaloacetic } \\
\text { Transaminase }\end{array}$ & $\begin{array}{l}\text { Glutamic-pyruvic } \\
\text { Transaminase }\end{array}$ & Alkaline Phosphatase & Cholinesterase \\
\hline $\begin{array}{r}1 \\
32 \\
51 \\
60 \\
72\end{array}$ & $\begin{array}{l}\text { Nitrogen mustards and } \\
x \text {-ray therapy }\end{array}$ & $\begin{array}{r}3.0 \\
5 \cdot 7 \\
13.2 \\
1.9 \\
1.2\end{array}$ & $\begin{array}{r}80 \\
90 \\
145 \\
30 \\
25\end{array}$ & $\begin{array}{r}26 \\
105 \\
130 \\
10 \\
7\end{array}$ & $\begin{array}{r}105 \\
132 \\
148 \\
64 \\
72\end{array}$ & $\begin{array}{r}45 \\
50 \\
64 \\
183 \\
100\end{array}$ \\
\hline
\end{tabular}


gives as much, if not more, guidance in the differential diagnosis of liver disease than would any more elaborate combination which included one or more of the plasma enzyme activities measured in the present work.

The second question was concerned with the possible value of serial measurements of multiple plasma enzyme activities in assessing the course of particular hepatic disorders. The results suggest that such estimations may give useful information but that it is not necessary to measure all the enzyme activities. Thus, the fluctuations in either of the transaminases (glutamic-oxaloacetic or glutamicpyruvic) reflected the major changes in any of the other enzymes studied. Abnormal values for the transaminases were obtained in acute hepatitis before overt jaundice had supervened and they appeared to be sensitive indices of a further episode of parenchymal damage during a severe hepatitis (Fig. 1). The abnormal values quickly returned to normal in an uncomplicated case of hepatitis (Table JII) and their persistently raised levels in the cases of cirrhosis (Table VI) and of hepatic metastases (Table VII) indicated continuing liver damage. A further point of interest was the return to normal of the high transaminase values in the patients with Hodgkin's disease who responded favourably totreatment (Table VII). The serial estimation of serum $\overline{\vec{s}}$ : transaminases would therefore be a valuable adjuncto to the other conventional liver function tests in the् assessment of the course of some types of liverw disease.

We are indebted to our clinical colleagues for allowing us to investigate the patients under their care.

\section{REFERENCES}

De la Huerga, J., Yesinick, C., and Popper, H. (1952). Amer. J. clin Path., 22, 1126.

Greenberg, D. M., and Harper, H. A. (1960). Enzymes in Health and $\vec{A}$ Disease. Thomas, Springfield, Illinois; Blackwell, Oxford.

Harrison, G. A. (1957). Chemical Methods in Clinical Medicine Churchill, London.

Kaltenbach, J. P., Becker, J. F., and Bernstein, I. (1957). Amer. J. clin. Path., 27, 309.

King, E. J. (1959). Amer. J. Med., 27, 849.

Maclagan, N. F. (1944). Brit. J. exp. Path., 25, 234.

Malloy, H. T., and Evelyn, K. A. (1937). J. biol. Chem., 119, 481.

Powell, M. E. A., and Smith, M. J. H. (1954). J. clin. Path., 7, 245.

Reitman, S., and Frankel, S. (1957). Amer. J. clin. Path., 28, 56.

Sibley, J. A., and Lehninger, A. L. (1949). J. biol. Chem., 177, $859 \vec{\sim}$

Sterkel, R. L., Spencer, J. A., Wolfson, S. K., and Williams-Ashman, , H. G. (1958). J. Lab. clin. Med., 52, 176.

Wolfson, S. K., and Williams-Ashman, H. G. (1957). Proc. Soc. exp Biol. (N. Y.), 96, 231. 